\title{
TRANSPORTATION POLICIES FOR JAKARTA'S CONGESTION
}

\author{
Rohana Sitanggang ${ }^{1}$, Euis Saribanon ${ }^{2}$ \\ 1. STMT Trisakti, 2. STMT Trisakti. \\ corresponding author: Rohana_dms@yahoo.com
}

\begin{abstract}
Traffic congestion in DKI Jakarta Province has become a very distressing problem. Due to the increasing number of vehicles and people's mobility, nowadays Jakarta is constructing more road infrastructures in several areas. To overcome the problem, DKI Jakarta needs quick and proper improvements involving various related parties. In the meantime, public's perception towards the policy of urban transportation system, especially in Jakarta, tends to classify certain party in which it leads to the users of private vehicle, and neglects the interest of people who mostly use public transportation. The aim of this study is to determine the most relevant policy on transportation system to overcome the congestion problem in DKI Jakarta. This study used qualitative research with Delphi method. Through the method of purposive sampling and quoted sampling, the writers found five informants from related agencies and experts, then Focus Grup Discussion (FGD) was conducted. The result showed that the policy of the most relevant transportation system is the one constructed together by all mutually integrated related parties
\end{abstract}

Keywords: Policy, Transportation, Congestion

\section{Introduction}

Not only traffic congestion, but Jakarta also faces many other transportation problems nowadays. They are the unexpected service of public transportation, contradictory tariff, high traffic violation and accidents (Kuntohadi, Pahala, \& Sitanggang, 2015), undisciplined road users, insufficient and disordered parking, and even the accessibility of disabled people to public transportation. In fact, all of the problems are mutually connected that cause a complex problem for the city.

The problem of traffic congestion in Jakarta is still unsolved. every year it haunts the people living in the capital city. The government has made various efforts to alleviate the traffic congestion such as providing public transportation called Bus Trans Jakarta. However, the public transportations provided are still not able to serve the need of the people. The shortage of bus fleets, the minimum bus halts, the malfunctioned public facilities and on-bus sexual harassments toward women passengers occur very often.

The complexity of transportation problems in the Jakarta province and 
the limited alternative solutions due to limited availability of land and fund require the government and related parties to plan and develop alternative solutions as efficient and effective as possible. The development of roadbased public transportation system in Jakarta is not relatively based on a good planning. It can be seen from the unstructured bus transportation system. As it is mentioned in Studi Perencanaan Transportasi Makro di DKI Jakarta (PPST UI, 2003), the public bus transportation system ideally refers to the concept of trunk line and feeder line which can create a more organized, efficient, effective, reachable and more environmental-friendly structure of public transportation route patterns.

Based on the above condition, the writers are interested in studying about which policy formulation on transportation system can alleviate the traffic congestion in Jakarta.

"Public policy is a decision aimed at overcoming the problem emerging in a certain activity done by the government agency in order to run the government.” (Mustopadidjaja A.R., 2003)

"The policy is made to direct, control, decide and operate acts. Especially in the government organizations, policy must be build in the context of a teamwork." (Soesilo, 2008)

Accordingly, it can be concluded that all alternatives constructed by the governmentis categorized as a public policy.

Furthermore, transportation not only runs to increase the rate of trade and production activity (Kadarisman, Yuliantini, \& Madjid, 2016), but it also facilitate the movement of raw materials to the processing location, even it helps a product reach the customer. Nowadays, a critical problem Indonesia faced is the limited facilities and infrastructure of land transportion. Indonesia, as a country with a very large land area, does not have sufficient road infrastructures.

The imbalance between road infrastructures and the number of vehicles has attracted attention from many parties. The poor facilities of road infrastructures causes many problems in land transport. The common definition of transportation is vehicles driven by human beings or machines 
used to move people or goods from one place to another. . Transportation is generally used to make people easier to do their daily activities.

Sudradjat, Sumartono, \& Asropi, (2011) in their journal said, "Traffic congestion usually increases along with the increasing mobility of transport users, especially in rush hours".

Traffic congestion happens because of some reasons, such as the poor system of traffic light setting, numerous cross roads, too many vehicles on the road, season, road condition,etcetera . Various efforts to overcome traffic congestion have been made including adding the road facilities, constructing highways, building flyovers and tunnels, improving the Area Traffic Control Sistem (ATCS), and many others.

Sukarto, (2006) had carried out a study to give description about the correlation between the environmental aspects and urban transport, entitled "Transportasi Perkotaan dan Lingkungan". The data used in the study comprises primary data and secondary data obtained from related parties. The analysis technique used a descriptive analysis method. The study concluded that there are some efforts can be made to overcome the transport problems related with environment, such as: urban spatial planning, urban traffic control, the use of alternative energy for environmental-friendly vehicles, promoting the use of bicycles and mass rapid trasnport (MRT).

(Najib, Z.Tamin, Sjarifuddin, \& Santoso, 2005) conducted a study to find the strategy for determining the roads in priority to be improved in Bandung entitled "Determination Priority of Road Improvement Alternative Based On Region Optimization, Case Study Bandung City Indonesia”. The data used in the study comprises primary data and secondary data obtained from related parties. The analysis technique used a process hierarchy analysis. Six criteria are analyzed, namely: travel time ratio, average travel time ratio, trip generation ratio, trip attraction ratio, residential density ratio, and employment density ratio. The study found that the improvement of road infrastructures was influenced more by residential density rather than by the level of road service. 


\section{Method}

The research uses purposive sampling and quoted sampling methods (Saribanon, Sitanggang, \& Amrizal, 2016). Purposive sampling is the sampling method by which the researchers take selected people based on the specific characteristics of the sample. Purposive sample is the sample carefully selected so that it is relevant with the research design. Whereas quoted sampling is the method to select samples with specific characteristics in the desired number or quota (Soeratno \& Arsyad, 2008).

Data collection is carried out in two ways: primary data collection and secondary data collection. Primary data collection is done through direct observation on the research location and interviews. Interview is the method for collecting data by directly asking questions to (or communicating with) respondents. The interview is conducted to key-persons, to the related agencies like BPTJ, Jakarta Provincial Agency of Transportation, Indonesia Police and transportation experts. The interview was delivered in written.(Saribanon \& Kurniawati, 2015)

The analysis tool used is Delphi method which is a decision making approach based on the survey to the expert opinions performed in stages, two or more stages.
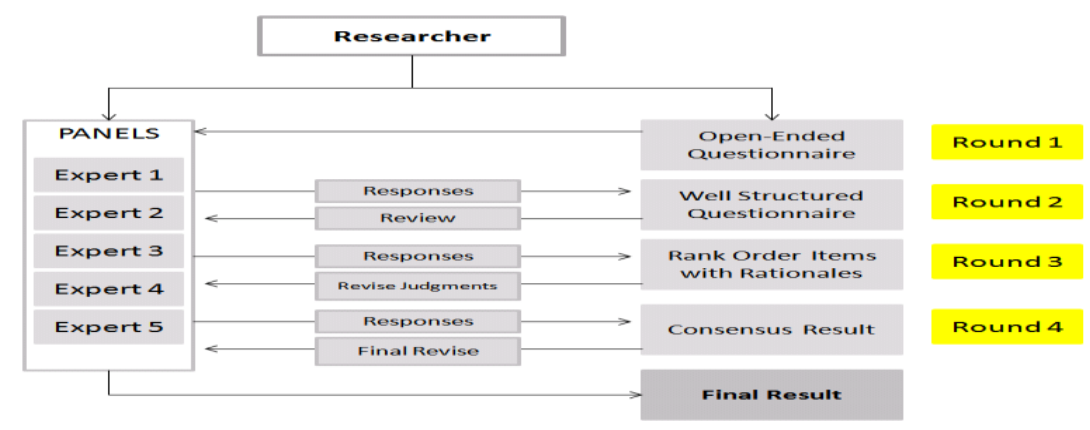

Source: Helmer, O., (1977).

Figure 1 . Delphi method.

\section{Discussion and Results}

Result

Condition of Congestion in Jakarta (BPTJ, 2017)

- Significantly decreased vehicle speed since 10 years ago

- In Jakarta, average speed at peak hour $10 \mathrm{~km} /$ hour

- Volume Capacity Ratio (VCR) in metropolitan area exceeded 1 
- Economic losses due to traffic congestion up to USD 1.3 billion (2010), and predicted to be USD 6.5 billion in 2020;

The Traffic congestion handling in Jakarta has been organized by implementing various policies on transportation system (Kadarisman et al., 2016), which can divided into two: short term solutions (Push \& Pull) and long term solutions (Land Use Policy).

The Push Policy operated includes: the implementation of Odd-Even System, Limitation on the use of Motorcycle, Electronic Enforcement, Limitation on Goods Transportation and Ramp Metering on Toll. Moreover, The Pull Policy operated includes: Park \& Ride, Shuttle Transport, Premium Transport JA and JR Connection, and HOV Line Public Transport.

The most important thing to be paid attention in the case of traffic congestion is the impact of the dysfunctioned transport system viewed from various causes: 1) Spatial arrangement, where the road construction is asynchronous with the transportation system. For example, so many housing complexes spread without sufficient road or access. 2) Incorrect approach and social orientation of the policy; the orientation of the policy is not integrated and only based on their own version. For example, Provincial Agency of Public Works (PU) only overcomes the problem by constructing roads, Provincial Agency of Industry only produces cheap vehicles. Those examples cause an impact on the Ministry of Transportation: traffic congestion.

The solution for traffic congestion, which is dominated by the use of private cars and road construction as well as institutional organization, does not run well. All the consequences are addressed to the use of private cars. The question is, what is the solution? The policy takes advantages of the available infrastructures through Need Management (PP. No. 32 Tahun, 2011), which is related to the unsynchronized public policy. For example, the Ministry of Transportation is eagerly developing some mass transports such as Bus Rapid Transit (BRT), Mass Rapid Transport (MRT), and Light Rail Transit (LRT), but these do not answer the question. MRT with its big capacity will be functioned well if the network is sufficient. LRT has a 
target to remove mikrolet and buses.

Development of public transport in Jabodetabek

1. Light Rail Transit (LRT), Jakarta Government / JAKPRO

2. Light Rail Transit (LRT), Ministry Of Transportation /Adhi Karya

3. Light Rail Transit (LRT), Jababeka

4. Mass Rapid Transit (MRT), PT. MRT

5. Airport Railway (CL dan Ekspress), PT. KAI

6. Jakarta - Bandung High-speed Train (KCIC)

7. Automatic People Mover system (APMS), Soekarno-Hatta Airport

8. Commuter Line (CL), PT. KCJ

9. Bus Rapid Transit (BRT), PT. Transjakarta

\section{Discussion}

The government has an institute which is competent in managing transportation problems, but it will not run well if all the parties do not coordinate and work together. The act to alleviate traffic congestions by adding infrastucture is considered effective, but this solution is expensive to be implemented or operated. Those acts are Constructing new roads, Increasing Infrastructure Capacity, Traffic Engineering and Management, making Policy on Parking, applying Public Transport Priority, building Highway (Toll), Inner City Highway, Outer Ring Road and New Connecting Roads. Furthermore, connecting two zones with very dense traffic, enlargement and improvement of crossgeometric, developing incongruent road-crosses, constructing new tunnel roads for interadministrative areas and constructing pedestrian bridge are the other actions

In order to implement or operate the above activities, it needs cooperation and coordination of all parties as well as evaluation of the Analysis on the Traffic Impact or Analisis Dampak Lalulintas (Andalalin) which involves some related parties. Until May 2017, 13 Andalalin documents have been proposed, and in the early stage there has been an evaluation done by BPTJ team, complete with field survey. However, all these documents have not fulfilled the administrative and technical requirements so they are returned to the consultants or developers to be 
completed and improved.

To find the impact of development and traffic performance, BPTJ specifically uses the software of Vissim which can integrate the result of analysis in the form of numbers with its 3-dimension visual display. The model of Vissim will give facilities to consultants and the evaluation team consisting of BPTJ, Ministry of Public Works and People's Housing and Traffic Coordinator of Indonesia Police (Korlantas POLRI).

It is necessary to hold an intense socialization to the developers/constructors that every development of activity center, housing complex and transportation infrastructure should be completed with the document of analysis on traffic impact. Unfortunately, some developers/constructors do not understand the regulation related to this. The adaptation from the consultant (third party) to the implementation of Vissim software or tool takes extensive time and process. The use of new unfamiliar software will be continuously socialized to the related stakeholders. Without supports from reliable human resources in transportation field who master the newest technology, there is a potential delay in accomplishing the document being evaluated. BPTJ should have anticipated these obstruction Stage I

Various efforts have been made by the Provincial Government of Jakarta (and the Central Government) to control traffic congestions, such as: the implementation of three-in-one lanes at certain hours on certain parts of road, the development of fly over and under pass at the cross roads, the implementation of mass transport with special bus lane system (bus way), the adjustment of working hours and school hours, and the enhancement of the quality and quantity of traffic facilities and infrastructures, the implementation of odd/even for private cars, and the limitation of twowheeled vehicles. However, those efforts have not been able to control the traffic congestion in Jakarta yet. In the contrary, the traffic congestion is getting worse and worse.

Stage II

The Provincial Government of Jakarta intends to limit the use of 
private cars, both two-wheeled and four-wheeled cars, to force the drivers to move to mass transport. However, the regulation can not run well if the alternative transports, especially mass transport, is not available. It is difficult to limit the use of vehicles. If we can change it as in the developed countries, people will follow (the regulation on vehicle limitation). The policy on the vehicle limitation has triggered some polemics, one of them is related to regional economy. In addition, another problem emerges: online transport. In deed, online transport emerges to fill in the space which is not served by formal public transports.

Therefore, before making a policy, it is necessary to fill in the market space which can not be served by today's formal transport. Moreoer, the policy itself should be able to provide efficient facilities for people. Never limit the number of vehicles unless the alternatives transportation is available.(Gunawan, Kadarisman, \& Ismiyati, 2016)

Strage III

The development of a good transportation system is a must, because a transportation system influences the urban spatial pattern and the growth of satelite cities very much. Thus, the urban development must be followed by the implementation of transportation policies that focus on motor vehicles. A number of inevitable problems is the logical consequences which burden an urban area.

The externality impacts in the forms of air pollution and noise caused by the transportation sector are parts of city government's concentration, since these are the impacts that people complain the most. However, as the area with majority people's daily activities are on the service and trade sectors, it needs policies which are suitable with the characteristics of its citizens' activities.

The transportation problems in the developing countries are not only technical, but also social ones, where in addition to its main function, transport also becomes a business and employment opportunity. If it is not for business and employment, then the government can establish a business entity which is subsidized to operate the mass transport system with big 
capacity and affordable ticket price. In a development country, It is the Government who occupies public transportation run by operators, and service purchasing and subsidies contribution. The government through public service approach (Pendekatan Pelayanan Publik) has organized the way private companies manage their transportation fleets in their routes. This has been carried out, but the results are not in accordance with the initial commitment.

Stage IV

Need Management controls "Transport Demand Management" (TDM) where each aspects can not stand separately. The TDM includes some measures to reduce the use of individual transport and to change the type of transportation demand to alleviate the congestion by managing the existing demand and controlling the growth of demand. Through TDM approach, the points should be completed are Controlling Vehicle Ownership, Increasing Vehicle Tax Cost, Vehicle Quotaand Garage Requirements, Controlling the Use of Vehicle, Uncharging Access Control, Basic Price and Controlling On-street Parking..

One of the efforts to improve the public transport services is that the government supposed implement Electronic Route Price (ERP), a solution to principally limit the use of private vehicles on certain corridors where the users should pay. In the other ways, the government should improves the service quality and public transportation capacity, increases the number of buses, create highway time, etc. So that the congestion will be decreased with the declining use of private vehicles and inclining number of public transportation like busway, since the basic idea of creating busway is the solution for congestion.

\section{Conclusion}

A policy formulation will not be able to alleviate congestion as long as each related party makes their own policy. There are some aspects that influence the policies on urban transport. For example, the planning aspect of road, and people or goods transport. This aspect includes general spatial 
plan and land use as well as transportation management. The aspect of coordination between the regulator and the operators includes governmental management, inter-institutional coordination and legislation. The aspect of environment includes the external impacts resulted.

The three aspects above are general aspects that the city government needs to pay special attention in order to create the expected transportation condition. If one of the aspects is neglected, the objectives of transportation will not be achieved. In implementing the concept of integrated transportation in a system, it is necessary to make these aspects to be the main references. The implementation of an integrated urban transportation system in a bigger system is aimed at alleviating the traffic congestion by increasing the use of public transport.

\section{References}

BPTJ. (2017). Program Integrasi Transportasi Jabodetabek 2017. In Seamless Transport Throgh Integration (p. 149). Jakarta: Badan Pengelola Transportasi Jakarta.

Gunawan, A., Kadarisman, M., \& Ismiyati. (2016). Kebijakan Manajemen Transportasi Darat Dan Dampaknya Terhadap Perekonomian Masyarakat Di Kota Depok. Jurnal Manajemen Transportasi Dan Logistik, 3(1), 41-58. https://doi.org/10.25292/j.mtl.v3i1.140

Kadarisman, M., Yuliantini, \& Madjid, S. A. (2016). Formulasi Kebijakan Sistem Transportasi Laut. Jurnal Manajemen Transportasi \& Logistik, 3(2), 161-183. https://doi.org/http://dx.doi.org/10.25292/j.mtl.v3i2.101

Kuntohadi, H., Pahala, Y., \& Sitanggang, R. (2015). Risk Management Analysis on The Car Drivers in Indonesia. Jurnal Manajemen Transportasi \& Logistik, 2(2), 221-226. https://doi.org/http://dx.doi.org/10.25292/j.mtl.v2i2.125

Mustopadidjaja A.R. (2003). Manajemen proses kebijakan publik: formulasi, implementasi, dan evaluasi kinerja (1st ed.). Jakarta: Lembaga Administrasi Negara.

Najib, Z.Tamin, O., Sjarifuddin, A., \& Santoso, I. (2005). Determination Priority Of Road Improvment Alternative Based on Region Optimization Case Study: Bandung City Indonesia. Proceedings of the Eastern Asia Society for Transportation Studies, 5, 1040-1049.

PP. No. 32 Tahun. Manajemen dan Rekayasa, Analisis Dampak, Serta Manajemen Kebutuhan Lalu Lintas (2011). Jaka: Kementerian Sekretariat Negara Republik Indonesia.

Saribanon, E., \& Kurniawati, R. R. (2015). Faktor-Faktor Penyebab Bermasalah. Jurnal Manajemen Bisnis Transportasi Dan Logistik, 
2(1), 129-149.

Saribanon, E., Sitanggang, R., \& Amrizal. (2016). Kepuasan Pengguna Jasa Transportasi Untuk Meningkatkan Loyalitas. Jurnal Manajemen Transportasi \& Logistik, 3(3), 317-326. https://doi.org/http://dx.doi.org/10.25292/j.mtl.v3i3.81

Soeratno, \& Arsyad, L. (2008). Metodologi Penelitian : Untuk Ekonomi \& Bisnis. Jogjakarta: UPP AMD YK.

Soesilo, N. I. (2008). Manajemen Sektor Publik (Pendekatan Praktis). Jakarta: Universitas Indonesia.

Sudradjat, Sumartono, O., \& Asropi. (2011). Model Jalan Lalulintas Jalan Tol Dalam Persamaan Diferendial Parsial. UNPAD.

Sukarto, H. (2006). Pemilihan Model Transportasi Di Dki Jakarta Dengan Analisis Kebijakan " Proses Hirarki Analitik ." Jurnal Tehnik Sipil, 3(1), 25-36. 